Faith in Flux 


\section{CONTEMPORARY ETHNOGRAPHY}

Kirin Narayan and Alma Gottlieb, Series Editors

A complete list of books in the series is available from the publisher. 


\title{
FAITH IN FLUX
}

Pentecostalism and Mobility in Rural Mozambique

\section{Devaka Premawardhana}

\author{
$\overline{\text { PENN }}$ \\ UNIVERSITY OF PENNSYLVANIA PRESS \\ PHILADELPHIA
}


Copyright (C) 2018 University of Pennsylvania Press

All rights reserved. Except for brief quotations used for purposes of review or scholarly citation, none of this book may be reproduced in any form by any means without written permission from the publisher.

\author{
Published by \\ University of Pennsylvania Press \\ Philadelphia, Pennsylvania 19104-4112 \\ www.upenn.edu/pennpress \\ Printed in the United States of America \\ on acid-free paper
}

135779108642

Library of Congress Cataloging-in-Publication Data

Names: Premawardhana, Devaka, author.

Title: Faith in flux : Pentecostalism and mobility in rural

Mozambique / Devaka Premawardhana.

Other titles: Contemporary ethnography.

Description: 1st edition. | Philadelphia : University of

Pennsylvania Press, [2018] | Series: Contemporary ethnography

| Includes bibliographical references and index.

Identifiers: LCCN 2017047730 | ISBN 978-0-8122-4998-9

(hardcover : alk. paper)

Subjects: LCSH: Pentecostalism-Mozambique. | Social mobility-Mozambique. | Residential mobility-Mozambique. |

Makhuwa (African people)- Mozambique. |

Mozambique-Religious life and customs. | Conversion. |

Pentecostal churches-Mozambique.

Classification: LCC BR1644.5.M85 P74 2018 | DDC 276.79/

083-dc23

LC record available at https://lccn.loc.gov/2017047730 
For Kalinka 
The sedentary life is the very sin against the Holy Spirit. -Friedrich Nietzsche, Twilight of the Idols 